\title{
Shock y hematuria en paciente anciana
}

\author{
Fumero Arteaga S, Vivancos Garbayo S, Figueroa Sosa V, Taracena Lafuente JM, Castro Díaz D, \\ Rodríguez Hernández P.
}

Hospital Universitario de Canarias. Santa Cruz de Tenerife.

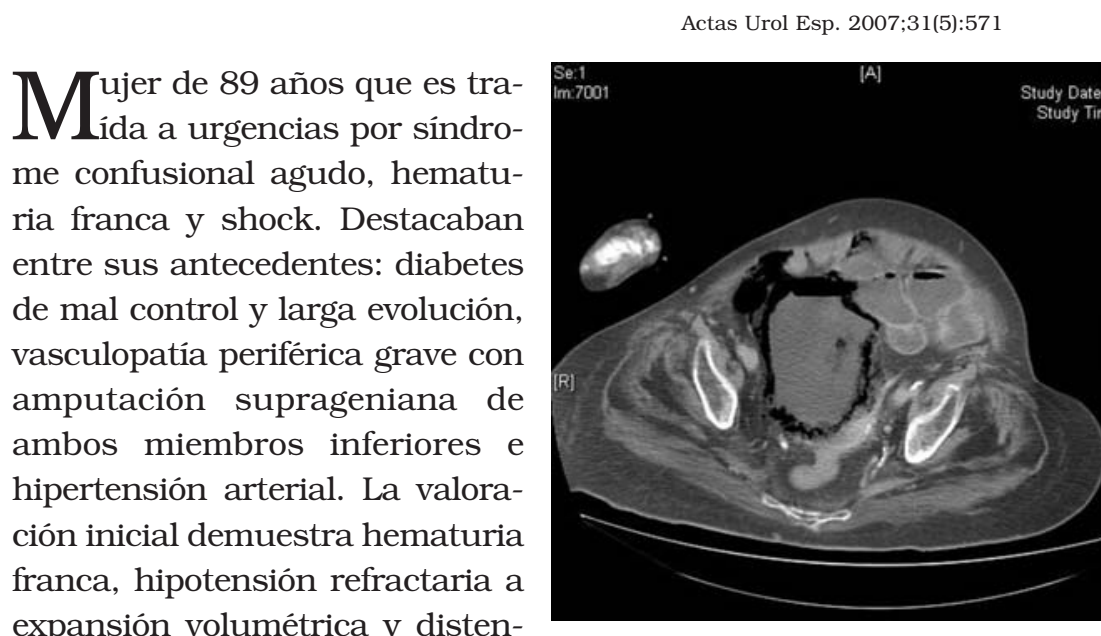

expansión volumétrica y distensión abdominal, asimismo presenta leucocitosis intensa e insuficiencia renal aguda. En este momento se realiza lavado vesical manual ante la sospecha de retención aguda de orina obteniendo escasa cantidad de orina y de coágulos. Tras intento infructuoso de ecografía abdominal por presencia de aire que dificulta la misma, se realiza TAC abdominopélvico donde se objetiva Cistitis Enfisematosa con perforación vesical y afectación del tejido graso perivesical y subcu-

\section{FIGURA 1}

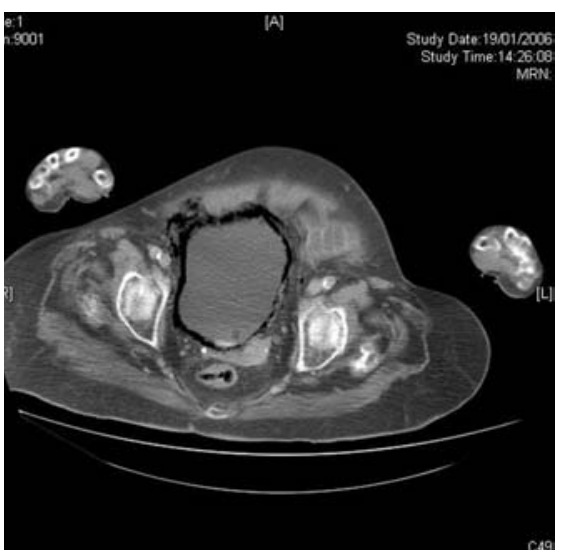

FIGURA 3

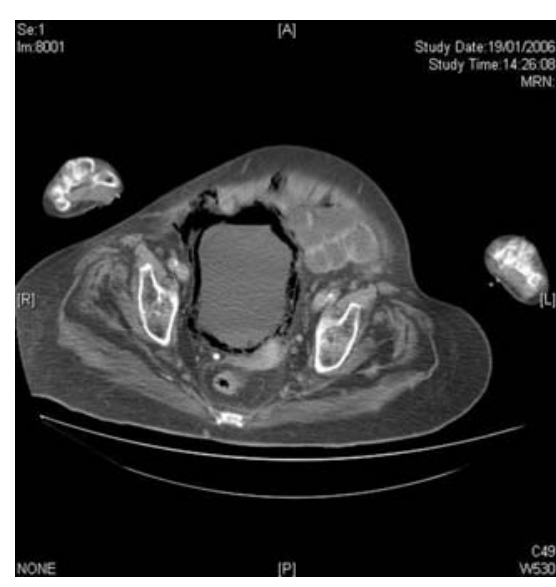

FIGURA 2

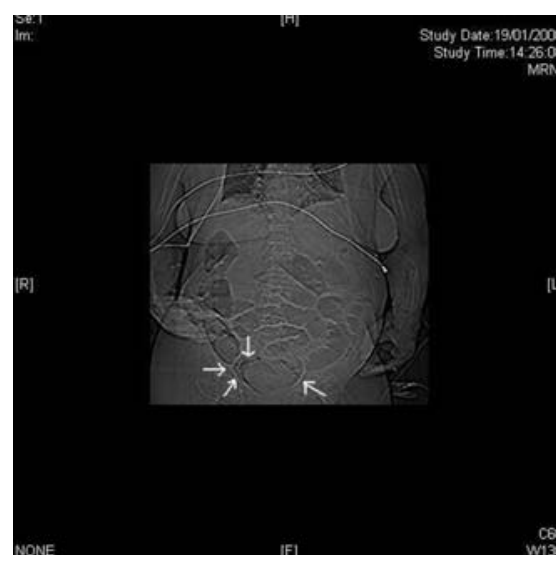

FIGURA 4 táneo (Fig. 1, 2, 3 y 4). En las imágenes se observan las paredes vesicales infiltradas por gas, formando un marco aéreo, así como perforación en el lado derecho y enfisema perivesical y subcutáneo. A pesar de tratamiento antibiótico agresivo y medidas de soporte la paciente falleció a las pocas horas del ingreso.

\footnotetext{
Correspondencia autor: Dr. Sergio Fumero Arteaga Hospital Universitario de Canarias Ofra, s/n - 38320 Sta. Cruz de Tenerife. Tel.: 922678800

E-mail autor: sergiofumero@hotmail.com Información artículo. Imágenes en urología Trabajo recibido: abril 2006

Trabajo aceptado: mayo 2006
} 